International Research Journal of Management, IT \& Social Sciences
Available online at https://sloap.org/journals/index.php/irjmis/
Vol. 9 No. 1, January 2022, pages: 58-66
ISSN: 2395-7492
https://doi.org/10.21744/irjmis.v9n1.2000

\title{
School Strategy in Developing Religious Character Education of Students at MTs Tangerang
}

\begin{tabular}{|c|c|c|}
\hline & CrossMark & Sutarman ${ }^{2}$ \\
\hline Article history: & Abstract & \\
\hline
\end{tabular}

Submitted: 09 September 2021

Revised: 18 October 2021

Accepted: 27 November 2021

\section{Keywords:}

character education;

habits;

religion;

school strategy;

students;
The purpose of this research is to find out the extent of the school's strategy to develop character education that is applied to students about religion and its habits. Research method with a qualitative approach that describes in detail and depth. Data collection techniques through (1) Interviews with key volunteers who know the focus of problems in the school (2). Survey of school locations as research sites, to find phenomena that occur as data to be used in research (3). Documentation studies in the form of photographs, data, archives, of the school so that it can be understood by related components such as principals, teachers, students, education staff, parents, and school committees (2). Implementation of running every program that has been designed properly and correctly, in accordance with the schedule and guidelines (3). An evaluation that oversees the implementation of the activities carried out so that it continues to be structured with the policies that have been planned so that the implementation is directed, as well as any programs that are running or those that have not been controlled and always provide direction.

International research journal of management, IT and social sciences (C) 2021. This is an open access article under the CC BY-NC-ND license (https://creativecommons.org/licenses/by-nc-nd/4.0/).

Corresponding author:

Sutarman,

Islamic Sheikh Yusuf University, Tangerang, Indonesia.

Email address: sutarman@unis.ac.id 


\section{Introduction}

The character of a nation is an important aspect, namely the quality of human resources because these qualities determine the quality of a nation (Naim, 2012). Quality characters need to be formed and nurtured. Character formation of students at MTsN 2 Tangerang. Failure to inculcate religious character in students will form problematic characters in the future of students. One of the efforts to strengthen and strengthen the nation's character is to implement character education for religious students in the school environment (Kurniawan et al., 2019). With efforts like this, in accordance with the regulations regarding character education numbered: 1860/C/TU/2011, namely regarding the implementation and implementation of character education which has been inaugurated its implementation

Character education is a process of giving good guidance to students to become fully human beings with Islamic character in the dimensions of heart, mind, body, taste, and intention. Because character education can be interpreted as education for the noble values of the nation (Fariha, 2018). character education, moral and moral education, character and character education, which has the aim of developing students' abilities to make good and bad decisions, to maintain what has been good, and to realize that goodness into everyday life wholeheartedly and forever. with the community and the environment

Moral problems that arise suddenly and uncontrollably. Events that disturb the community and educational institutions such as student brawls and group brawls, skipping school, damaging the environment, vandalism, acts of violence, drug addiction, rape, and persecution. All of these problems involve students, youth, and youth (Danim, 2016). Cheating and lying behavior is a small part of the moral deviation of school students. Some good qualities as the basis of morality as: being empathetic, conscientious, self-monitoring and controlling, respecting others, doing good, being tolerant, and doing justice. As for other issues that are being discussed by the community, such as the presence of students who dare to yell, bully their teachers in the classroom, which is witnessed by other students. Even though other students opposed and intervened, the other students did not react to prevent or give warnings but instead seemed to let the class atmosphere become noisy and not conducive. This is certainly not good and very bad, especially in the application of character education, so it should be noted that religious character education needs to be prioritized so that academic education, science, and technology are balanced (Bogdan et al., 1975; Hibana et al., 2015).

That is supporting students' knowledge, the school needs to provide a variety of subjects that are balanced between general lessons and religious lessons. This needs to be applied so that students master aspects of general knowledge and aspects of religious knowledge. The scientific aspects given to students are not only through classroom learning but are also taught through daily activities or actions such as shaking hands with teachers at school, praying before starting lessons, reading Asmaul Husna, praying dhuha in the congregation, and praying dzuhur. together. Activities in the application of religious aspects such as the dzuhur prayer activities. Students are required to pray dzuhur in the congregation in the school mosque. Carrying out worship, students are required to carry out the dhuhur prayer in congregation, although the implementation is alternate because there is still a lack of facilities for places of worship to accommodate all students when the dhuhur prayer is carried out in congregation (Mayarani, 2014; Muslich, 2011; Yudianti, 2018).

\section{Materials and Methods}

1) Research Approach

Qualitative approach research by defining it as a research procedure that produces descriptive data in the form of written or spoken words from people as key informants in obtaining data, in having a number of different characteristics from other researchers.

2) Type of Research

The type of research used is case studies, the research design used is used in cases. With a discussion related to the strategy of developing the character of religious students at MTSN-2 Tangerang with a research focus on implementing school strategies in developing the character of religious students.

3) Research Instruments

As a characteristic of qualitative research with observations that play a role, namely the researcher who determines the scenario (Sugiyono, 2015). Researchers in research as a key instrument, as participants, and also as data collectors. While the other instruments areas support.

Sutarman, S. (2022). School strategy in developing religious character education of students at MTs Tangerang. International Research Journal of Management, IT and Social Sciences, 9(1), 58-66. 


\section{Data collection technique}

1) Observations and observations in research by observing the symptoms that appear on the object of research, either directly or indirectly using observations and observations

2) In-depth interviews as a process of obtaining data needed by research by face-to-face interviews with informants

3) Documentation to find data in the form of notes, books, newspapers, magazines, inscriptions, document films, minutes of meetings, ledgers, agendas, and what is needed by researchers

\section{Results and Discussions}

\section{Strategic planning for the development of religious character education for MTSN-2 Tangerang students}

The scope of the MTSN-2 Tangerang school strategy consists of developing the vision and mission, school goals, identifying opportunities and threats at MTsN 2 external to the school, and determining the school's internal strengths and weaknesses, setting the school's long-term goals (Hanafiah \& Suryani, 2021). make a series of strategies as an alternative in solving problems that exist in schools, and choose certain strategies to run.

1) Vision and Mission Vision as the views and ideals of the school that is far ahead. The vision and the school can be used as a guide in moving the program of school activities. Without a vision for the school, activities will be tossed around in carrying out management, learning for religious students

2) The characteristics and characteristics are as follows: (a). Activities should focus on objectives (b). MTSN 2 teachers as implementers must be able to grasp the meaning and understand to run school programs (c). MTSN 2 Tangerang teachers can understand the program to be applied to students (d). The program can be implemented as well as realistic and objective with students at MTSN 2 Tangerang

\section{Religious, excellent, character and Islamic school}

The characteristics of the MTSN-2 Tangerang school are as follows: (a). Simple and focused (b). The program is religious (c). The goal is affordable for both teachers and students (d). Easy to implement. Make it easy for teachers, students, and other school components. The program with the motto Religious, Superior, Character and Islamic, is an activity that is simple, easy, and superior and enters into the religious characteristics of students. In addition, the meaning of the religious characteristics of students in a program will be carried out in this research. Easy to run, simple to convey, and easy to understand by students and other school members (Ene \& Barna, 2015; Spörer \& Brunstein, 2009). There are several religious indicator items at MTSN 2 Tangerang. These indicators include (1). Growing students' religious behavior as a manifestation of faith and piety (2). Fostering students' enthusiasm for charity and habituation sincerely (3). Realizing student character as student behavior that is religious and has good character (4). Realizing students' awareness to establish congregational prayers when they are at school (5). Maintaining order when carrying out worship, reading prayers and memorizing the Qur'an, and memorizing Asmaul Husna

\section{Strategic environmental observation}

Strategies in environmental activities are very important that must be carried out by schools by identifying sources of strategic environmental observations (Jalil, 2016). The source of observation has three levels, namely: (a). Task environment as a resource related to the main tasks and functions, school components, school units, school capabilities, and school structure. (b). The school environment is a school component that is related to other schools, which are considered to have a relationship with each other with schools, both public and private (c). The macro-environment includes social, political, economic, cultural, scientific, and technological capacities that can affect schools either directly or indirectly.

1) Task environment as a resource related to the main tasks and functions, positions within the school, school units, school capacity, and school structure. The MTsN-2 Tangerang school has several activities that have been developed at the school. Religious programs, for example, are the culture of praying at school, every morning before going to class, then reading Asmaul Husna, dhuha prayer activities, midday prayers in congregation at 
the mosque. Qur'anic verse memorization deposit activities guided by the teacher. In accordance with the grade level, religious practices to support students' knowledge such as the practice of praying jama' and qoshor, the practice of Friday sermons, cult practices, every prayer reading activity, and so on. As the development of students' religious character in aspects of habituation, aspects of knowledge, aspects of worship, aspects of practice.

2) Environment users who are related to other schools that have a relationship with each other, with public or private schools. As the development of religious character education for students of MTsN-2 Tangerang. Is a school that deals with the development of students' religious character education. This has been realized in the form of routine activities for MTsN-2 students. Students take part in student internships at Islamic boarding schools. The lessons taught are the yellow book recitation, the tahfidz qur'an program, the Arabic language deepener. In the aspect of religious knowledge and aspects of religious practice.

3) The macro-environment includes social aspects, political aspects, economic aspects, cultural aspects as well as science and technology that can have a direct impact on schools. MTSN-2 Tangerang School has social activities that are carried out at the end of each year, namely on the Eid al-Qurban (Zubaedi, 2015). The social activity of slaughtering sacrificial animals is held every year in different locations outside the school. Public recitation activities by inviting speakers from outside the school. Students distribute necessities such as rice, instant noodles, suitable clothing, and so on to the surrounding community. This is a form of student religious character education in the aspect of religious practice. In each activity, there are religious aspects of students such as aspects of learning and deepening religion, aspects of religious knowledge, aspects of religious practice, and aspects of sharia economics.

\section{Strategic target of MTSN-2 Tangerang school}

Strategic goals are programs to be achieved and describe general terms that are relative and know no time limit. The targets are formulated within the framework of the school's vision and mission. The school's targets are strategic goals related to the vision to be achieved (Mesiono, 2010). In formulating the goals and objectives of the school, it is necessary to develop a method that is characteristic of MTsN-2 Tangerang. Have goals that have been clearly defined with specific goals. The attitude of the statement of goals and objectives must be measurable. This indicates that the attitude statement and goals can be achieved, by utilizing existing resources and can be responsible.

\section{SWOT strategy analysis}

In making a strategic plan, schools can take advantage of information about internal factors and external factors in order to formulate and formulate school plans appropriately and accurately. SWOT analysis is a way to map out strategic options that can be used in schools (Juwono, 2012). By comparing internal factors, namely strengths and weaknesses, external factors, namely opportunities and threats. The SWOT matrix produces four alternative strategies, namely:

1) Strategy Competition (S-O). Competition strategy is a strategy that uses strength to take advantage of opportunities. This strategy can be used when the school is in a strong position and many opportunities have been identified.

2) Strategy Mobilization (S-T). A mobilization strategy is a strategy that uses strength to overcome threats. The strategy will be chosen if the school has sufficient strength, but outside the MTSN-2 Tangerang school environment, there are still threats that must be faced.

3) Investment Strategy (W-O). The investment strategy is to minimize weaknesses to be able to take advantage of opportunities. So schools can take advantage of existing opportunities, to increase strength. A strategy to be used when the school is in a weak condition but there are many opportunities available.

4) Damage Control Strategy (W-T), namely the damage control strategy is a strategy that minimizes weaknesses and avoids existing threats. In this strategy, schools must eliminate weaknesses and threats simultaneously. This strategy can be used when schools face many threats with weak conditions and situations

MTSN 2 Tangerang uses several approaches in determining the right strategy in implementing the development of students' religious character education in schools

Sutarman, S. (2022). School strategy in developing religious character education of students at MTs Tangerang. International Research Journal of Management, IT and Social Sciences, 9(1), 58-66. 
Table 1

SWOT analysis of strength strategies to take advantage of opportunities

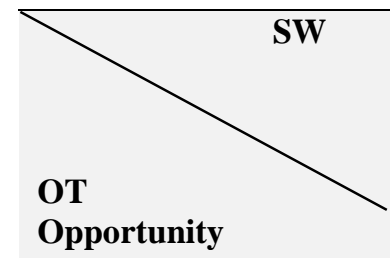

Determine as many as 5

- 10 external

opportunity factors

Threat

Determine as many as

5-10 external threat

factors

Strength
Determine $5-10$ as many
internal strength factors

SO Strategy

Using strengths by taking

advantage of

opportunities

\section{ST strategy}

Creating strategies using strengths in the face of threats

\section{Weakness}

Determine $5-10$ as many internal weakness factors WO Strategy

Creating strategies by minimizing weaknesses to take advantage of opportunities WT Strategy

Creating strategies by minimizing weaknesses and eliminating threats

(Source: Data processed 2020)

\section{Strategic implementation of religious character education development for MTSN-2 Tangerang students}

\section{Strategy competition $(\mathrm{S}-\mathrm{O})$}

Based on the previous explanation that MTSN-2 Tangerang (Sutarman et al., 2017). The school has several strengths, including the following: (1). Habituation was carried out in improving the religious character education of students. (2). The practice is done every morning until coming home from school. (3). Develop students' religious character education in aspects of religious practice, aspects of belief, and aspects of appreciation (3). Shake hands with students to the teachers (4). Read the prayer before starting the lesson (5). Read the Koran and Asmaul Husna. (6). Practicing worship by carrying out dhuha prayers and dhuhur prayers in congregations in mosques that have schools. (7). Deposit memorization of Quranic verses to teachers in their respective classes. (8). Organizing ta'lim assemblies as a forum for students to develop student character education. Schools have the opportunity to develop students' religious character education. These opportunities are: having students who excel in the field of religion, winning: tahfidz quran, calligraphy, MTQ, MSQ, Arabic speech, Islamic intelligence, and musabaqoh competitions, all proven by the awards in the form of trophies at school. Those schools use the strengths of existing schools to be exploited into existing opportunities. With this, it can be proven that MTSN 2 Tangerang uses a competition (S-O) strategy (Nangimah, 2018; Ningsih, 2017; Suda, 2017).

\section{Investment strategy $(\mathrm{W}-\mathrm{O})$}

If the school has a weakness because it cannot target students in achieving the targets set by the school as a whole. In this case the school must find ways and methods so that the weaknesses in the school can be minimized. Using the teacher providing material for students who have not reached the target. This method has been provided by the school by providing a mentor, for activities that have been approved by the principal through a decree (Junaedi, 2018). This method can be used to develop the education of students' religious character, with aspects of religious knowledge. Students are guided and taught how to read the Qur'an with basic materials such as Iqro 'until students understand and can read the Qur'an. Weaknesses continue and are minimized by teachers and schools to get school opportunities, which can make students excel in the field of religious science in students. This is known as the investment strategy (W-O). Schools can use two strategies as such. As for the Mobilization Strategy (S-T) and the Damage Control Strategy (W-T), the MTSN-2 Tangerang school was not used, because the school did not have threats from other competing schools. Schools consider that other schools as competitors at other times can be partners for collaboration. That like this shows the school is focused on increasing the strength of the school to get the opportunities that exist and minimizing the weaknesses of the school (Ridwan et al., 2018; Rodliyah, 2016; Barnes, 2000). 
Strategic evaluation of the development of religious character education for MTSN-2 Tangerang students

\section{School strategic policy}

Schools are formal educational institutions that implement educational policies that have been determined by the ministry of education and culture. However, the MTSN-2 Tangerang school has school-based management that can manage it independently. Policies made by schools that are developed independently by schools. School policies describe government policies and regulations, by looking at the phenomena and various problems that exist in the school. Schools have good policies according to their management, according to the programs they have, and their implementation which will provide a framework for school components (Samani, 2013; Sobri, 2017; Ülger et al., 2014).

Curriculum policy and its development in the fields of mathematics, science, language, and extracurricular activities. School development is aimed at improving the quality of graduates. School policies are the strengths and weaknesses of the school itself, such as educational staff who have good character and morals, become school habits and culture, establish relationships with the community, and pioneer networks with other institutions to obtain school funds (Rokhman et al., 2014; Pane \& Patriana, 2016). Development of school policies and curriculum in achieving success as the implementation of strategies that include the following:

1) School communication system is very important in developing curriculum effectively and efficiently

2) Implementation of the vision, a mission that must be built, and its implementation based on the agreement of all school components

3) School development strategies are made jointly by receiving input from school components and stakeholders

4) Principals can delegate responsibilities to vice-principals, teachers, and students if deemed important so that the principal's performance becomes effective in allocating time and developing his performance.

5) Community and stakeholder support in providing trust built through open and transparent communication

6) Requires proper supervision and assessment and maximizes existing human resources in schools

7) Make maximum efforts in increasing school resources and cooperation with the wider and more beneficial community.

The school has policies that have been made, namely extracurricular activities related to the field of religious character education by participating in the Ta'lim Council. The Ta'lim Assembly is an extracurricular activity at MTSN-2 Tangerang (Hermawan, 2010). Religious activities are carried out by students, as for the program at the Ta'lim Council, namely routine recitations every Sunday held at the mosque. Recitation is a manifestation of the development of students' religious character and instills aspects of faith, aspects of practice and aspects of appreciation. Students who take part in recitation activities and khatam al-Qur'an, increase faith in religion so that they can practice every teaching of the Islamic religion sincerely. Carry out hadrah albanjari, calligraphy and muhadhoroh training as additional lessons with local mutants containing the recitation of the yellow book that is tailored to the abilities of each student. local content lessons filled with yellow book lessons, all activities are students' religious character education lessons that include aspects of knowledge, which explore Islamic religious lessons by deepening the yellow book (Cheung \& Lee, 2010; Suhifatullah et al., 2021).

The development of students' religious character is through activities carried out in ma'had, namely learning the yellow book, the tahfidz qur'an program, Arabic deepening. Ma'had is a place for students who will develop students' religious character, increase faith, religious understanding, appreciation, practice, which is taught twenty-four hours. This policy is a school development as an implementation of government policy. Policies that exist in MTSN-2 Tangerang (Andjarwati, 2015). It is a form of school development to improve the quality of school graduates. Motivation is an absolute thing given to all components of the school so that they can get used to and practice the teachings of Islam that have been studied. Motivation aims to increase students' enthusiasm so that their performance can increase. Supervision of performance conditions and the relationship between school components. The factor of student satisfaction in participating in each activity motivates students for performance with an emphasis on factors related to the performance of the students themselves, which can be obtained directly from participating in each program of activities (Utami, 2014; Wibowo, 2012; Manea, 2014).

School resource allocation

Sutarman, S. (2022). School strategy in developing religious character education of students at MTs Tangerang. International Research Journal of Management, IT and Social Sciences, 9(1), 58-66. https://doi.org/10.21744/irjmis.v9n1.2000 
Education is an important aspect of a nation, with education a nation will be strong and advanced. Preparing a superior next generation is the task of all people who are gathered in education as agents of change. Good education is education provided by schools in which there is learning and several other supporting factors, namely human resources as school managers. available resources in schools is a factor supporting the success of graduate learning outcomes. Schools as agents of change have resources that can be utilized to achieve educational goals (Ainiyah \& Wibawa, 2013). Facilities and infrastructure as a support for educational progress that can be used directly by educational institutions for teaching and learning activities for students that can improve students' intellectual intelligence, media and visual aids as teaching tools. Infrastructure as a facility that supports the implementation of educational activities such as buildings and other objects as a unit in realizing superior education. Educational facilities and infrastructure that are properly equipped can support the management of quality education which will lead to excellent students who are ready to face the challenges of the times (Wekke \& Sahlan, 2014; Croitoru \& Munteanu, 2014).

Managers and providers of school facilities must pay attention to the conditions and situations as well as the concepts outlined in the education program as a school curriculum development implemented by MTSN-2 Tangerang. So that what is needed by education can be fulfilled with the infrastructure provided. MTSN-2 Tangerang school has complete facilities and infrastructure, in developing the religious character of students including ma'had, mosques, student memorization deposits, classic books about history and past Islamic civilization, hadrah albanjari and so on. Development and addition of learning buildings as a form of facilities and infrastructure to build student ma'had. So with the construction of ma'had and mosques at MTSN-2 Tangerang, it can be expected to improve the religious character of students in all aspects of religious scholarships, such as aspects of belief, worship, appreciation, knowledge, and practice of students taught at MTSN-2 Tangerang (Abdullah, 2014). Can improve students' practice in aspects of general knowledge and religious knowledge and can be directly practiced in everyday life

\section{Conclusion}

Based on the results and discussion above relating to the development of students' religious character, it can be concluded that:

1) Strategic planning that formulates the development of religious character education for students at MTSN-2 Tangerang. Has several sections such as: (a). The school's vision and mission are Religious, Superior, Character and Islamic. (a). Observe the Islamic school environment by using the task environment, users, organization environment, and macro environment. (b). The school's goals and objectives are: Specific, Measurable, Attainable. Responsible (c). Perform a SWOT analysis. namely the Competition Strategy (S-O) and Investment Strategy (W-O), while the Mobilization Strategy (S-T) and Damage Control Strategy (W-T) did not use because the school had no threats or competitors.

2) The school's implementation strategy is to develop religious character education for MTSN-2 Tangerang students. Has several aspects, namely: (a). School policy (b). Holding extracurricular activities carried out at the Ta'lim Council (c). Applying local content lessons that contain the yellow book recitation that is tailored to students' abilities (d). Building a ma'had that has a special program for tahfidz qur'an and Arabic deepening

3) Strategic evaluation by supervising and motivating teachers and education personnel including (a). At the flag ceremony (b). At the official meeting with teachers and education staff (c). At the outbound event (d). Giving awards to outstanding teachers such as exemplary teachers, disciplined teachers and productive teachers, as well as to students by providing scholarships to outstanding students such as competition winners and those who are tahfizh al-Qur'an. (d). Forming ma'had and building mosques, depositing student memorization, studying classical books, memorizing hadrah albanjari, and so on.

\section{Conflict of interest statement}

The author declared that he have no competing interests.

Statement of authorship

The author has a responsibility for the conception and design of the study. The author has approved the final article.

Acknowledgments

I am grateful to two anonymous reviewers for their valuable comments on the earlier version of this paper. 


\section{References}

Abdullah, M. (2014). Management and Employee Performance Evaluation. Yogyakarta: Publisher Aswaja Pressindo.

Ainiyah, N., \& Wibawa, N. H. H. P. (2013). Pembentukan karakter melalui pendidikan agama Islam. Al-Ulum, 13(1), 25-38.

Andjarwati, T. (2015). Motivation from the Point of View of Maslow's Hierarchy of Needs Theory, Herzberg's TwoFactor Theory, McGregor's X Y Theory, and McClelland's Achievement Motivation Theory". Journal of Economics and MTsN 2 management. Vol. 1 No.1.

Barnes, L. P. (2000). Ninian Smart and the phenomenological approach to religious education. Religion, 30(4), 315332. https://doi.org/10.1006/reli.2000.0291

Bogdan, R., Taylor, S. J., \& Taylor, S. S. (1975). Introduction to qualitative research methods: A phenomenological approach to the social sciences. Wiley-Interscience.

Cheung, C. K., \& Lee, T. Y. (2010). Improving social competence through character education. Evaluation and program planning, 33(3), 255-263. https://doi.org/10.1016/j.evalprogplan.2009.08.006

Croitoru, I., \& Munteanu, H. (2014). The Moral-Religious Education-A Support of Self-Conscience Training. Procedia-Social and Behavioral Sciences, 116, 2155-2163. https://doi.org/10.1016/j.sbspro.2014.01.536

Danim, S. (2016). Visi baru manajemen sekolah.

Ene, I., \& Barna, I. (2015). Religious education and teachers' role in students' formation towards social integration. Procedia-Social and Behavioral Sciences, 180, 30-35. https://doi.org/10.1016/j.sbspro.2015.02.081

Fariha, N. L. (2018). Peran Manajerial Kepala Sekolah dalam Meningkatkan Budaya Mutu Pendidikan (Studi Kasus di MAN 2 Ponorogo) (Doctoral dissertation, IAIN Ponorogo).

Hanafiah, S., \& Suryani, I. (2021). The Effect of Science in Development of Student Character Education with the Application of HOTS. LINGUISTICA ANTVERPIENSIA, 2861-2873.

Hermawan, R. (2010). Pengembangan sumber daya sekolah. Jurnal Pendidikan Dasar, 2(1), 68.

Hibana, H., Kuntoro, S. A., \& Sutrisno, S. (2015). Pengembangan pendidikan humanis religius di madrasah. Jurnal Pembangunan Pendidikan: Fondasi dan Aplikasi, 3(1), 19-30.

Jalil, A. (2016). Karakter Pendidikan untuk Membentuk Pendidikan Karakter. Nadwa, 6(2), 175-194.

Junaedi, E. (2018). Manajemen Pengembangan Sumber Daya Sekolah Dalam Meningkatkan Mutu Pembelajaran. Jurnal Pendidikan Islam Rabbani, 2(2).

Juwono, O. (2012). Analisis Manajemen Strategik Perusahaan Waralaba (Franchise) Studi Kasus di Restoran Cepat Saji McDonald'S. Jurnal Ekonomika Dan Manajemen, 1(1).

Kurniawan, A. M., Samsudi, S., \& Alimah, S. (2019). Implementation Of Religious Character Planting Of Low Grade Elementary School Students Learning In Islamic Elementary School In Purwokerto City. Educational Management, 8(2), 231-239.

Manea, A. D. (2014). Influences of religious education on the formation moral consciousness of students. ProcediaSocial and Behavioral Sciences, 149, 518-523. https://doi.org/10.1016/j.sbspro.2014.08.203

Mayarani, S. (2014). Peran Komite sekolah dalam pengadaan sarana dan prasarana di SD negeri Pucang IV Sidoarjo. Inspirasi Manajemen Pendidikan, 4(4).

Mesiono, M. (2010). Kebijakan pendidikan dan pengembangan sekolah (School Development). Jurnal Tazkirah, 2(2), $2-15$.

Muslich, M. (2011). Pendidikan karakter.

Naim, N. (2012). Character Building Optimizing the Role of Education in Science Development and National Character Building. Yogyakarta: Ar-Ruzz.

Nangimah, N. (2018). Peran guru PAI dalam pendidikan karakter religius siswa SMA N 1 Semarang (Doctoral dissertation, UIN Walisongo Semarang).

Ningsih, W. A. (2017). Pendidikan karakter religius melalui pembiasaan shalat dzuhur berjamaah kelas V di SD Islam Al-Madina Kota Semarang tahun 2016/2017 (Doctoral dissertation, UIN Walisongo).

Pane, M. M., \& Patriana, R. (2016). The significance of environmental contents in character education for quality of life. Procedia-Social and Behavioral Sciences, 222, 244-252. https://doi.org/10.1016/j.sbspro.2016.05.153

Ridwan, R., Tobroni, T., \& Khozin, K. (2018). Formation Of The Religious Character Of Students Based On Religious Education In Smk Negeri 2 Malang. EDUKASI: Jurnal Pendidikan Islam (e-Journal), 6(2), 001-014.

Rodliyah, S. (2016). Manajemen Pondok Pesantren Berbasis Pendidikan Karakter (Studi Kasus di Pondok Pesantren "Annuriyyah" Kaliwining Kecamatan Rambipuji Kabupaten Jember). Cendekia: Jurnal Kependidikan Dan Kemasyarakatan, 12(2), 299-314.

Sutarman, S. (2022). School strategy in developing religious character education of students at MTs Tangerang. International Research Journal of Management, IT and Social Sciences, 9(1), 58-66. 
Rokhman, F., Hum, M., \& Syaifudin, A. (2014). Character education for golden generation 2045 (national character building for indonesian golden years). Procedia-Social and Behavioral Sciences, 141, 1161-1165. https://doi.org/10.1016/j.sbspro.2014.05.197

Samani, M. (2013). Konsep dan Model Pendidikan Karakter, Cet. 3.

Sobri, A. Y. (2017). Manajemen Pendidikan Karakter Berbasis Religi di Sekolah Dasar. Sekolah Dasar: Kajian Teori dan Praktik Pendidikan, 24(1), 18-25.

Spörer, N., \& Brunstein, J. C. (2009). Fostering the reading comprehension of secondary school students through peerassisted learning: Effects on strategy knowledge, strategy use, and task performance. Contemporary Educational Psychology, 34(4), 289-297. https://doi.org/10.1016/j.cedpsych.2009.06.004

Suda, I. K. (2017). The The children character improvement through painting activities in art school: I Wayan Gama Painting School. International Research Journal of Management, IT and Social Sciences, 4(4), 11-21. Retrieved from https://sloap.org/journals/index.php/irjmis/article/view/470

Sugiyono, S. (2015). Metode penelitian kombinasi. Bandung: Alfabeta.

Suhifatullah, M. I., Sutarman, S., \& Thoyib, M. (2021). Character education strategies in improving students' spiritual intelligence. International Research Journal of Management, IT and Social Sciences, 8(2), 155-162. https://doi.org/10.21744/irjmis.v8n2.1350

Sutarman, S., Edi Hermawan, H., \& Ahmad, A. (2017). Character education to build personal learners tough. IOSR Journal of Research \& Method in Education (IOSRJRME), 7(1), 59-63.

Ülger, M., Yiğittir, S., \& Ercan, O. (2014). Secondary school teachers' beliefs on character education competency. Procedia-Social and Behavioral Sciences, 131, 442-449. https://doi.org/10.1016/j.sbspro.2014.04.145

Utami, A. T. (2014). Pelaksanaan nilai religius dalam pendidikan karakter di SD Negeri 1 Kutowinangun Kebumen. $S$. Pd Skripsi. Universitas Negeri Yogyakarta.

Wekke, I. S., \& Sahlan, A. (2014). Strategy in creating school environment: lessons from high schools in indonesia. Procedia-Social and Behavioral Sciences, 143, 112-116. https://doi.org/10.1016/j.sbspro.2014.07.370

Wibowo, A. (2012). Character Education: Strategies for Building the Character of a Civilized Nation. Yogyakarta: Student Library.

Yudianti, A. L. (2018). Implementasi Visi dan Misi Sekolah dalam Membina Karakter Religius Siswa (Studi Komparasi di SMP N 8 Yogyakarta dan SMP N 1 Yogyakarta) (Doctoral dissertation, Tesis UIN Sunan Kalijaga Yogyakarta).

Zubaedi, M. A. (2015). Desain Pendidikan Karakter. Prenada Media. 